\title{
GAMBARAN PENCABUTAN GIGI DI POLI GIGI DAN MULUT PUSKESMAS KOTA BARAT KOTA GORONTALO TAHUN 2016 - 2018
}

\author{
Abdulhafids Daud ${ }^{1}$, Anneke Tahulending ${ }^{2}$, Jeineke Ratuela ${ }^{3}$ \\ 1) Dinas Kesehatan Propinsi Gorontalo Jl.P Hidayat Kota Tengah Kota Gorontalo \\ 2,3)Jurusan Keperawatan Gigi Poltekkes Kemenkes Manado jl.RW Monginsidi Malalayang Manado \\ Email : ahafidsdaud@gmail.com
}

\begin{abstract}
ABSTRAK
Pendahuluan: Masalah kesehatan gigi di Indonesia khususnya karies gigi dan penyakit periodontal masih tinggi yaitu mencapai lebih dari $80 \%$. Kondisi ini memicu tindakan pencabutan gigi sehingga prevalensi pencabutan gigi meningkat. Penelitian difokuskan pada tindakan pencabutan gigi berdasarkan karakteristik pasien, baik pencabutan gigi sulung maupun permanen di poliklinik gigi Puskesmas Kota Barat Kota Gorontalo antara tahun 2016 dan 2018. pendidikan dan pekerjaan. Metode: Jenis penelitian ini adalah studi dokumen deskriptif yang dilaksanakan pada tahun 2019 di Klinik Gigi dan Mulut Puskesmas Kota Barat Kota Gorontalo. Sampel penelitian berjumlah 249 orang yaitu seluruh kunjungan pasien dengan pencabutan gigi antara tahun 2016-2018. Instrumen penelitian yang digunakan dalam penelitian ini adalah formulir karakteristik pasien, alat tulis dan buku register. Data yang diperoleh kemudian ditabulasi dan disajikan dalam bentuk tabel distribusi frekuensi. Hasil: Berdasarkan hasil penelitian didapatkan bahwa pencabutan gigi di Puskesmas Kota Barat antara tahun 2016 - 2018 berdasarkan kelompok umur tertinggi pada kelompok umur 6-11 tahun yaitu 40,56\% berdasarkan jenis kelamin menunjukkan 54,62\% perempuan sedangkan 45,38\% laki-laki Berdasarkan tingkat pendidikan, tingkat pendidikan tertinggi adalah pendidikan SD yaitu $40,56 \%$, berdasarkan pekerjaan tertinggi siswa yaitu $43,37 \%$ dan untuk pencabutan gigi tetap 56,51\% dan pencabutan gigi sulung $43,49 \%$.
\end{abstract}

Kata kunci: Pencabutan Gigi, Puskesmas

\section{ABSTRACT}

Introduction : Dental health problems in Indonesia, especially dental caries and periodontal disease, are still high, reaching more than $80 \%$. This condition triggers the action of tooth extraction so that the prevalence of tooth extraction increases. The study focused on the action of tooth extraction based on patient characteristics, both primary and permanent teeth extraction in the dental polyclinic of the West City Health Center, Gorontalo City, between 2016 and 2018. education and work. Methods : This type of research is a descriptive document study, which was carried out in 2019 at the Dental and Oral Clinic of the West City Health Center, Gorontalo City. The research sample consisted of 249 people, namely all patient visits with tooth extraction between 2016-2018. Research instruments used in the study were patient characteristic forms, writing instruments and register books. The data obtained is then tabulated and presented in the form of a frequency distribution table. Result : Based on the results of the study, it was shown that tooth extraction at the West City Health Center between 2016 - 2018 based on the highest age group was the age group 6-11 years, namely $40.56 \%$ based on gender showing $54.62 \%$ women while $45.38 \%$ men Based on the level of education, the highest level of education is SD education, namely $40.56 \%$, based on the highest occupation is students, namely 43.37\% and for permanent tooth extraction $56.51 \%$ and primary tooth extraction $43.49 \%$.

Key words : Tooth Extraction, Public Health Centre 


\section{PENDAHULUAN}

Seiring dengan lajunya perkembangan ilmu pengetahuan dan teknologi diberbagai bidang, maka harapan atas pemenuhan kebutuhan dasar masyarakat semakin meningkat. Untuk itu Pembangunan diberbagai bidang terus digalakkan Oleh pemerintah guna memenuhi tuntutan akan kebutuhan masyarakat tennasuk pembangunan dibidang Kesehatan. Tujuan pembangunan kesehatan adalah terciptanya masyarakat Indonesia yang hidup dan bemrilaku dalam lingkungan sehat dan mampu menjangkau pelayanan kesehatan yang bemutu. Dipihak Iain pelayanan kesehatan yang diberikan di seluruh wilayah Indonesia harus dilakukan secara adil, merata dan optimal. ${ }^{1}$

Masalah dibidang kesehatan merupakan masalah yang sangat dinamis dan terus berkembang seiring dengan perkembangan jaman. Diantaranya adalah masalah kesehatan gigi, khususnya penyakit gigi dan mulut menjadi pHoHtas untuk mendapatkan perhatian yang serius. Penyakit gigi dan mulut yang paling banyak di temukan baik di negara maju maupun negara yang sedang berkembang adalah karies gigi dan penyakit periodontal. Masalah kesehatan gigi di Indonesia, khususnya karies gigi dan penyakit periodontal masih tinggi mencapai lebih dari $80 \% .^{2}$

Dari data Riskedas 2018 tersebut menunjukan bahwa proporsi masalah kesehatan gigi dan mulut di Provinsi Gorontalo berada diatas ratarata nasional. ${ }^{3}$

Survei awal di Puskesmas Kota Barat Kota Gorontalo pada tanggal 8 April 2019, bahwa poliklinik gigi Puskesmas Kota Barat melaksanakan pelayanan setiap hari Senin sampai dengan Sabtu. Poli gigi Puskesmas Kota Barat Kota Gorontalo memberikan pelayanan kesehatan gigi dan mulut antara lain pencabutan gigi, penambalan gigi, pembersihan karang gigi, pemasangan gigi palsu, pemberian Obat dan lain-lain. Berdasarkan buku register kunjungan pasien di poliklinik gigi tahun 2016 sampai dengan tahun 2018 berjumlah 4.173 Kunjungan pasien tahun 2016 berjumlah 1.542 orang dengan pencabutan gigi sebanyak 64 orang (4,15\%), kunjungan pasien tahun 2017 berjumlah 1.741 orang dengan pencabutan gigi sebanyak 103 orang $(5,92 \%)$ dan kunjungan pasien tahun 2018 berjumlah 890 orang dengan pencabutan gigi sebanyak 82 orang $(9,21 \%)$.

Berdasarkan data bulan Januari sampai dengan bulan Maret 2019 diperoleh jumlah pencabutan gigi adalah 23 orang yang terdiri dati jenis kelamin lakilaki 10 orang, perempuan 13 orang. Dan apabila dikelompokan berdasarkan kelompok umur, maka diperoleh data sebagai berikut; kelompok umur 0-5 tahun 0 orang, 5-11 tahun 6 orang, 12-25 tahun 3 Orang, 26-35 tahun 0 Orang, 36-45 tahun 4 Orang, 46-55 tahun 3 orang, $56-65$ tahun 7 orang dan 65 tahun keatas 0 orang.

Berdasarkan latar belakang permasalahan di atas, maka penulis tertarik untuk melakukan penelitian tentang kunjungan pasien dengan tindakan pencabutan gigi berdasarkan karakteristik pasien dan berdasarkan pencabutan gigi sulung dan gigi tetap di poliklinik gigi Puskesmas Kota Barat Kota Gorontalo selang waktu tahun 2016 - 2018.

Tujuan penelitian ini adalah untuk mengetahui gambaran kunjungan pasien pencabutan gigi berdasarkan karakteristik pasien, pencabutan gigi sulung dan gigi tetap di poli gigi dan mulut di Puskesmas Kota Barat Kota Gorontalo tahun 2016 2018

\section{METODOLOGI}

Jenis penelitian ini adalah studi dokumen dengan pendekatan deskriptif dengan maksud untuk mendeskripsikan kunjungan pasien pencabutan gigi berdasarkan karakteristik umur jenis kelamin, Tingkat Pendidikan, Pekerjaan dan pengelompokan berdasarkan gigi sulung dan gigi permanen pada poli gigi dan Mulut Puskesmas Kota Barat Kota Gorontalo selang Tahun 2016 - 2018

Penelitian ini dilaksanakan pada bulan Mei - Juni 2019. Penelitian ini dilaksanakan di Puskesmas Kota Barat Kota Gorontalo

\section{Definisi Operasional}

1. Kunjungan pasien adalah kunjungan pasien dengan pencabutan gigi di poligigi dan mulut Puskesmas Kota Barat yang diukur berdasarkan data register pasien berdasarkan karakteristik 
dan pencabutan gigi sulung dan gigi tetap selang waktu tahun 2016 - 2018.

2. Karakteristik adalah : Keadaan tertentu atau ciri khas pasien Poli Gigi dan Mulut pada Puskesmas Kota Barat berdasarkan umur, jenis kelamin, pendidikan dan pekerjaan.

3. Umur adalah usia responden tanpa memperhitungkan tanggal dan bulan kelahiran. Kategori umur yang dimaksud yaitu semua umur yang teflera di buku register kunjungan pasien.

4. Jenis Kelamin adalah perbedaan fisik dari responden (laki-laki dan perempuan).

5. Tingkat Pendidikan adalah jenjang pendidikan yang pemah diikuti oleh responden (SD, SIMP, SMA dan Perguruan Tinggi).

6. Pekerjaan adalah aktifitas yang digeluti oleh pasien untuk menghidupi atau menafkahi keluarga.

7. Gigi sulung adalah gigi yang pertama tumbuh pada manusia sebelum mengalami pergantian dengan gigi tetap, yang dilakukan tindakan pencabutan gigi berdasarkanjenis/macam gigi sulung.

8. Gigi tetap adalah gigi pennanen yang tumbuh sebagai pengganti gigi sulung atau gigi susu yang dilakukan tindakan pencabutan gigi berdasarkan jeni/macam gigi tetap..

Populasi dalam penelitian ini menggunakan data sekunder berupa buku register kunjungan pasien dengan pencabutan gigi tahun 2016 - 2018 berjumlah 249 orang. Sampel yang digunakan dalam penelitian ini yaitu total populasi yang berjumlah 249 orang.

\section{HASIL}

Puskesmas Kota Barat merupakan salah satu Puskesmàs yang ada di Kota Gorontalo, terletak di Kelurahan Buladu Kecamatan Kota Barat, dengan wilayah kerja terdiri dari empat Kelurahan termasuk Kelurahan Buladu. Secara geografis Puskesmas Kota Barat Kota Gorontalo Sebelah Utara berbatasan dengan Kecamatan Dungingi , Sebelah Selatan berbatasan dengan Kecamatan Kota Selatan, Sebelah Barat berbatasan dengan Kecamatan Telaga Kabupaten Gorontalo, Sebelah Timur berbatasan dengan Kecamatan Kota Tengah.
Poliklinik gigi Puskesmas Kota Barat melaksanakan pelayanan pasien setiap hari senin s/d Sabtu. Petugas kesehatan gigi terdiri dari 2 orang perawat gigi dan 1 orang dokter gigi. Poliklinik gigi dilengkapi dengan 1 buah dental unit yang digunakan untuk melayani pasien yang berkunjung ke poliklinik gigi

\section{Distribusi Kunjungan Pasien Pencabutan Gigi Berdasarkan Kelompok Umur.}

Tabel.1 Distribusi kunjungan pasien pencabutan berdasarkan umur.

\begin{tabular}{|c|c|c|c|c|c|c|c|c|}
\hline \multirow{3}{*}{$\begin{array}{c}\text { Kelom } \\
\text { pok } \\
\text { Umur }\end{array}$} & \multicolumn{8}{|c|}{ JUMLAH KUNJUNGAN } \\
\hline & \multicolumn{2}{|c|}{$\begin{array}{c}\text { TAHUN } \\
2016\end{array}$} & \multicolumn{2}{|c|}{$\begin{array}{c}\text { TAHUN } \\
2017\end{array}$} & \multicolumn{2}{|c|}{$\begin{array}{c}\text { TAHUN } \\
2018\end{array}$} & \multirow{2}{*}{$\begin{array}{l}\text { JM } \\
\mathbf{L}\end{array}$} & \multirow[t]{2}{*}{$\%$} \\
\hline & $\begin{array}{c}\text { JM } \\
\mathrm{L}\end{array}$ & $\%$ & JML & $\%$ & $\begin{array}{c}\mathrm{JM} \\
\mathrm{L}\end{array}$ & $\%$ & & \\
\hline $0-5$ & 1 & 1,56 & 0 & 0,00 & 1 & 1,22 & 2 & 0.80 \\
\hline $6-11$ & 22 & $\begin{array}{c}34,3 \\
8\end{array}$ & 40 & $\begin{array}{c}38,8 \\
3\end{array}$ & 39 & $\begin{array}{c}47.5 \\
6\end{array}$ & 101 & $\begin{array}{c}40.5 \\
6\end{array}$ \\
\hline $12-25$ & 6 & 9,38 & 9 & 8.78 & 3 & 3,66 & 18 & 7,23 \\
\hline $26-35$ & 6 & 9,38 & 16 & $\begin{array}{c}15,5 \\
3\end{array}$ & 7 & 8,54 & 29 & $\begin{array}{c}11,6 \\
5\end{array}$ \\
\hline $36-45$ & 5 & 7,81 & 11 & $\begin{array}{c}10,6 \\
8\end{array}$ & 10 & $\begin{array}{c}12,2 \\
0\end{array}$ & 26 & $\begin{array}{c}10,4 \\
4\end{array}$ \\
\hline $46-55$ & 16 & 25.0 & 16 & $\begin{array}{c}15,5 \\
3\end{array}$ & 10 & $\begin{array}{c}12.2 \\
0\end{array}$ & 42 & $\begin{array}{c}16,8 \\
7\end{array}$ \\
\hline $56-65$ & 5 & 7,81 & 8 & 77,7 & 10 & $\begin{array}{c}12,2 \\
0\end{array}$ & 23 & 9,24 \\
\hline$>66$ & 3 & 4,69 & 3 & 2.91 & 2 & 2.44 & 8 & 3.21 \\
\hline $\begin{array}{c}\text { TOTA } \\
\text { L }\end{array}$ & 64 & 100 & 103 & 100 & 82 & 100 & 249 & 100 \\
\hline
\end{tabular}

\section{Distribusi Kunjungan Pasien pencabutan} Gigi Berdasarkan Jenis Kelamin.

Tabel.2 Distribusi kunjungan pasien Pencabutan Gigi berdasarkan Jenis kelamin

\begin{tabular}{|c|c|c|c|c|c|c|c|c|}
\hline \multirow{3}{*}{$\begin{array}{c}\text { Jenis } \\
\text { kelamin }\end{array}$} & \multicolumn{6}{|c|}{ Jumlah kunjungan } & \multirow{3}{*}{ Jml } & \multirow{3}{*}{$\%$} \\
\hline & \multicolumn{2}{|c|}{2016} & \multicolumn{2}{|c|}{2017} & \multicolumn{2}{|c|}{2018} & & \\
\hline & $\mathbf{n}$ & $\%$ & $\mathbf{n}$ & $\%$ & $\mathbf{n}$ & $\%$ & & \\
\hline Laki-laki & 28 & 43.7 & 47 & 45.6 & 38 & $\begin{array}{l}46 . \\
3 \\
\end{array}$ & 113 & 45.4 \\
\hline $\begin{array}{l}\text { Perempua } \\
\mathrm{n}\end{array}$ & 36 & 56.3 & 56 & 54.4 & 44 & $\begin{array}{l}53 . \\
7 \\
\end{array}$ & 136 & 56.2 \\
\hline Total & 64 & 100 & 103 & 100 & 82 & 100 & 249 & 100 \\
\hline
\end{tabular}

3. Distribusi Kunjungan Pasien pencabutan Gigi Berdasarkan Tingkat Pendidikan 
Tabel 3. Distribusi kunjungan pasien pencabutan gigi berdasarkan tingkat pendidikan

\begin{tabular}{|c|c|c|c|c|c|c|c|c|}
\hline \multirow{3}{*}{$\begin{array}{c}\text { Tingkat } \\
\text { pendidika } \\
\text { n }\end{array}$} & \multicolumn{6}{|c|}{ Jumlah kunjungan } & \multirow{3}{*}{ Jml } & \multirow{3}{*}{$\%$} \\
\hline & \multicolumn{2}{|c|}{2016} & \multicolumn{2}{|c|}{2017} & \multicolumn{2}{|c|}{2018} & & \\
\hline & $\mathbf{n}$ & $\%$ & $\mathbf{n}$ & $\%$ & $\mathbf{n}$ & $\%$ & & \\
\hline TK & 1 & 1.6 & 0 & 0.0 & 1 & 1.2 & 2 & 0.8 \\
\hline SD & 22 & 34.4 & 40 & 38.8 & 39 & 47.6 & 101 & 40.6 \\
\hline SMP & 2 & 3.1 & 5 & 4.9 & 3 & 36.6 & 1 & 4.0 \\
\hline SMA & 29 & 45.3 & 41 & 39.8 & 27 & 32.9 & 10 & 38.9 \\
\hline PT & 10 & 15.6 & 17 & 16.5 & 12 & 14.7 & 97 & 15.7 \\
\hline Total & 64 & 100 & 103 & 100 & 82 & 100 & 211 & 100 \\
\hline
\end{tabular}

\section{Distribusi Kunjungan Pasien pencabutan Gigi Berdasarkan Pekerjaan}

Tabel 4. Distribusi kunjungan pasien pencabutan gigi berdasarkan pekerjaan.

\begin{tabular}{|c|c|c|c|c|c|c|c|c|}
\hline \multirow{3}{*}{ Pekerjaa } & \multicolumn{6}{|c|}{ Jumlah kunjungan } & \multirow{3}{*}{ Jml } & \multirow{3}{*}{$\%$} \\
\hline & \multicolumn{2}{|c|}{2016} & \multicolumn{2}{|c|}{2017} & \multicolumn{2}{|c|}{2018} & & \\
\hline & $\mathbf{n}$ & $\%$ & $\mathbf{n}$ & $\%$ & $\mathbf{n}$ & $\%$ & & \\
\hline Guru & 0 & 0 & 7 & 6,8 & 0 & 0 & 7 & 2.2 \\
\hline Polisi & 4 & 6.2 & 2 & 1.9 & 2 & 2.4 & 8 & 3.2 \\
\hline ASN & 9 & 14.1 & 9 & 8.7 & 4 & 4.9 & 22 & 8.8 \\
\hline Tukang & 4 & 6.2 & 8 & 7.8 & 4 & 4.9 & 16 & 6.4 \\
\hline Pensiunan & 5 & 7.8 & 3 & 2.3 & 5 & 6.1 & 13 & 5.2 \\
\hline Petani & 0 & 0 & 0 & 0 & 1 & 1.2 & 1 & 0.4 \\
\hline $\begin{array}{l}\text { Mahasisw } \\
\text { a }\end{array}$ & 5 & 7.8 & 8 & 7.8 & 3 & 3.7 & 16 & 6.4 \\
\hline IRT & 11 & 17.2 & 14 & 13.6 & 9 & 11 & 34 & 13.1 \\
\hline Swasta & 4 & 6.2 & 6 & 5.8 & 12 & 14.7 & 22 & 8.8 \\
\hline Siswa & 21 & 32.8 & 46 & 33.7 & 41 & 50.0 & 108 & 43.4 \\
\hline $\begin{array}{l}\text { Prasekola } \\
\mathrm{h}\end{array}$ & 1 & 1.6 & 0 & 0 & 1 & 1.2 & 2 & 0.8 \\
\hline
\end{tabular}

\section{Distribusi pencabutan Gigi Berdasarkan Pengelompokan Jenis Gigi}

Tabel 5. Distribusi pencabutan gigi berdasarkan jenis gigi.

\begin{tabular}{|c|c|c|c|c|c|c|c|c|}
\hline \multirow{3}{*}{ Jenis Gigi } & \multicolumn{6}{|c|}{ Jumlah kunjungan } & \multirow{3}{*}{ Jml } & \multirow{3}{*}{$\%$} \\
\hline & \multicolumn{2}{|c|}{2016} & \multicolumn{2}{|c|}{2017} & \multicolumn{2}{|c|}{2018} & & \\
\hline & $\mathbf{n}$ & $\%$ & $\mathrm{n}$ & $\%$ & $\mathrm{n}$ & $\%$ & & \\
\hline Gigi sulung & 27 & 39.1 & 44 & 39.6 & 46 & 51.7 & 117 & 43.5 \\
\hline Gigi tetap & 42 & 60.9 & 67 & 60.4 & 43 & 48.3 & 152 & 56.5 \\
\hline Total & 69 & 100 & 111 & 100 & 89 & 100 & 269 & 100 \\
\hline
\end{tabular}

\section{PEMBAHASAN}

Pada penelitian yang dilakukan Berikut ini dapat diuraikan pembahasan atas hasil penelitian berdasrkan karakteristik pasien dan berdasarkan kunjungan pasien pencabutan gigi sulung dan gigi tetap.

Berdasarkan hasil penelitian terkait kunjungan pasien pencabutan gigi ditinjau dari kelompok umur menunjukan bahwa, $40,56 \%$ pasien pencabutan gigi pada Puskesmas Kota Barat adalah kelompok umur 611 tahun. Kondisi ini terjadi karena pada kelompok usia 6-11 tahun sangat rentan terhadap kerusakan gigi akibat kebiasaan mengkonsumsi makanan yang dapat memicu terjadinya gigi berlubang, serta pada kelompok usia tersebut masih belum bisa menjaga kebersihan gigi dan mulut secara ideal. Disamping itu kondisi ini dapat dikonfinnasi dengan tabel 5 dimana pencabutan gigi sulung pada Puskesmas Kota Barat Kota Gorontalo mencapai 43,49\% dari total pencabutan gigi selang tahun 2016 sampai dengan 2018.

Hasil penelitian berdasarkan kelompok umur 6 11 tahun adalah usia rawan terjadinya kerusakan gigi sehingga harus diwaspadai, dan perlu beroleh perhatian khusus baik dari para orang tua dan para petugas kesehatan gigi dan mulut untuk lebih meniti beratkan program UKGS dalam hal upaya-upaya promotive dan preventif pada anak usia 6-11 tahun. Karena pada usia ini anak-anak harus ada perhatian khusus dari orang tua karena gigi geligi yang ada masih gigi campuran, dan orang tua beranggapan gigi -gigi yang ada masih gigi sulung sehingga mengabaikan akan kebersihan dan kesehatan giginya, karena akan tergani dengan gigi tetap, begitu juga dengan gigi geraham pertama baik untuk rahang atas maupun rahang bawah anggapan orang tua bahwa gigi iti adalah gigi sulung dqn masih akan diganti atau bertumbuh lagi, sehinggah kalau sudah terjadi lubang, dibiarkan saja, nanti kalau tidak bisa tahan sakitnya, orang tua akan membawah anak ke sarana pelayanan kesehatan untuk dicabut. Selain faktor umur yang terkait dengan masalah kesehatan gigi, faktor jenis kelamin juga terkait dengan masalah ini Berdasarkan kunjungan pasien pencabutan gigi ditinjau dari jenis kelamin menunjukan bahwa, 54,62\% pasien pencabutan gigi pada Puskesmas Kota Barat adalah perempuan sedangkan laki-laki 45,38\%. Dengan demikian antara laki-laki dan perempuan perbedaanya cukup signifikan. Hasil penelitian ini sejalan dengan hasil 
penelitian terdahulu yang dilaksanakan oleh Ngangi (2013) dimana dalam hasil penelitianya di Di Balai Pengobatan Rumah Sakit Gigi Dan Mulut Universitas Sam Ratulangi selang Tahun 2012 menggambarkan bahwa $62.51 \%$ pencabutan gigi terjadi pada jenis kelamin perempuan, sedangkan laki-laki sebanyak 37,49\%. ${ }^{4}$ Berdasarkan teori yang dikemukakan oleh Volker dan Russel (1993), mengatakan bahwa prevalensi karies gigi tetap wanita lebih tinggi dibanding dengan pria. Demikian juga halnya pada anakanak, prevalensi karies gigi sulung anak perempuan sedikit lebih tinggi dibanding anak laki-laki. Hal ini disebabkan antara lain erupsi gigi anak perempuan lebih cepat dibanding anak laki-laki. ${ }^{5}$

Selain faktor umur yang terkait dengan masalah kesehatan gigi, faktor jenis kelamin juga terkait dengan masalah ini. Hasil dari penelitian ini dapat dilihat bahwa kunjungan pasien pencabutan gigi tetap berdasarkan jenis kelamin adalah jenis kelamin perempuan yang tertinggi sebanyak 251 responden $(53,6 \%)$ dibanding laki-laki 217 responden $(46,4 \%)$. Hal ini terjadi karena perempuan mempunyai kebiasaan mengkonsumsi makanan manis diantara waktu makan terutama pada anak perempuan, dan juga erupsi gigi tetap pada jenis kelamin perempuan lebih cepat dari jenis kelamin laki - laki sehingga gigi lebih lama terpapar air ludah dan sisa makanan dan jika kebersihan gigi dan mulut terabaikan akan mempercepat proses karies gigi.

Menurut Tarigan (2013), bahwa presentase karies gigi pada wanita lebih tinggi dibandingkan dengan pria, hal ini disebabkan karena faktor pengunyahan dan mengabaikan dalam melakukan kebersihan gigi dan mulut. Dan juga perempuan pada masa kehamilan dimana terjadi ketidakseimbangan hormonal mengakibatkan peradangan gusi (pregnancy gingivitis) sehingga memudahkan perlekatan dari plak, hal ini diperparah lagi karena perempuan seringkali mengabaikan kebersihan gigi dan mulut pada masa ini, mengakibatkan presentasi karies gigi lebih tinggi pada perempuan dibanding dengan laki-laki. ${ }^{6}$ Hasil penelitian ini berbeda dengan yang didapatkan oleh Harlindong (2014) di Puskesmas Tinumbala Kecamatan Aertembaga Kota Bitung, yaitu jenis kelamin laki - laki sebanyak 17 responden $(53,1 \%)$ tertinggi dalam melakukan pencabutan gigi tetap dan jenis kelamin perempuan sebanyak 15 responden $\left(46,9 .^{7}\right.$ Dengan demikian dapat disampaikan bahwa selain faktor umur, jenis kelamin, faktor tingkat Pendidikan juga sangat mempengaruhi tingkat pencabutan gigi dari hasil penelitian terkait kunjungan pasien pencabutan gigi ditinjau dari tingkat pendidikan menunjukan bahwa, $40,56 \%$ pasien pencabutan gigi pada Puskesmas Kota Barat adalah pendidkan SD. Berdasarkan tabel 1 dimana pasien pencabutan gigi terbanyak terjadi pada anak usia $6-11$ tahun yang rata-rata adalah Siswa SD yaitu sejumlah 101 pasien atau sama dengan 40,56\%.bahwa tingkat pendidikan sangat mempengaruhi kesehatan gigi seseorang, semakin rendah tingkat pendidikanya semakin rendah pemahaman dan kebiasaannya dalam menjaga kesehatan gigi dan mulutnya. Berdasarkan hasil penelitian terkait kunjungan pasien pencabutan gigi ditinjau dari pekerjaan menunjukan bahwa, 43,37\% pasien pencabutan gigi pada Puskesmas Kota Barat adalah siswa. Hal ini di sebabkan kecenderungan dsri para siswa untuk konsumsumsi makanan makanan yang manis dan mudah melekat pada sat jam istirahat, dan jajan ini juga sangat mudah untuk mereka peroleh karena tersedia di kantin-kantin sekolah, siswa juga pada saat setelah jajan tidak pernah menyikat gigi, kemudian siswa juga kurang atau mengabaikan kesehatan gigi dn mulut, diman mereka nanti datang berobat apabila keadaan gigi sudah lubang, yang agak dalam, sehingga untuk perawatan atau untuk dilakukan penambalan sudah tidak memungkinkan lagi, dan harus dilakukn pencabutan gigi. Dengan demikian siswa merupakan kelompok yang memiliki resiko tinggi terhadap kerusakan gigi sehingga berpotensi untuk dilakukan pencabutan gigi. Dilihat dari kunjungan pasien pencabutan gigi berdasarkan jenis gigi anatara sulung dan gigi tetap. menunjukan bahwa, 43,49\% pasien pencabutan gigi pada Puskesmas Kota Barat adalah pencabutan gigi tetap dan 56,51 \% adalah pencabutan gigi tetap.hal ini terjadi karena banyak gigi tetap yang melakukan pencabutan gigi adalah gigi geraham pertama, dan diihat dari jumlah kunjungan berdasarkan usia adalah umur $6-11$ tahun, hal ini menunjukkan baik anak -anak maupun orang tua mengabaikan keersihan gigi dan mulut, orang tua dan anak-anak menganggap bahwa gigi geraham pertam itu adalah gigi susu yang masih bsa diganti atau akan tumbuh lagi, sehingga jika terjadi gigi lubang kurang mendapat perhatian, disamping itu gigi ini merupakan gigi geraham tetap yang tumbuh, sehingga sudah lama tekontminasi dengan 
airludah dan kuman dalam rongga mulut, dan jika kebersihan gigi dan mulut diabaikan akan menyebabkan gigi tersebut cepat rusak atau lobamg. Perbandingan antara pencabutan gigi sulung dan gigi tetap ini hampir seimbang, dengan kata lain bahwa peluang terjadinya kerusakan gigi antara gigi sulung dan gigi tetap nyaris sama yang pada giliranya mengakibatkan pencabutan gigi. Khusus gigi sulung bisa jadi angka tersebut merupakan kontribusi dari gigi goyang akibat akan mengalami pergantian dengan gigi tetap, sehingga orang tua banyak mengantar anak-anaknya untuk melakukan pencabutan gigi

\section{KESIMPULAN}

Berdasarkan hasil penelitian dan Kesimpulan dari penelitian ini pencabutan gigi pada puskesmas kota barat selang tahun 2016-2018 sebanyak 269 responden. Pencabutan gigi berdasarkan kelompok umur, 6-11 tahun sebanyak 101 responden (40,5\%), berdasarkan jenis kelamin tertimggi jenis kelamin perempuan sebanyak 136 responden $(54,6 \%)$ tingkat pendidikan yang tertinggi yaitu tingkat pendidikan SD sebanyak 101 responden, sedangkan untuk pekerjaan yang tertinggi yaitu siswa 108 responden $(43,3 \%)$ sedangkan berdasarkan jenis gigi tertinggi terdapat pada pencabutan tetap dengan jumlah responden $152(56,5 \%)$

\section{SARAN}

Berdasarkan kesimpulan tersebut diatas, maka disarankan hal-hal sebagai berikut.

1. Upaya-upaya promotive dan preventifterhadap anak usia sekolah perlu terus dilaksanakan dan ditingkatkan guna mencegah terjadinya kerusakan gigi yang berakibat pada pencabutan gigi.

2. Kaum perempuan utamanya ibu hamil lebih beresiko terhadapa kerusakan gigi sehingga perlu dibeii perhatian khusus dalam upaya-upaya promotifdan preventif untuk mencegah teijadinya kerusakan gigi yang berakibat pada pencabutan gigi. Misalnya setiap kunjungan ibu hamil ke Puskesmas yaitu ke Poli KİA dan KB dirujuk ke poli gigi dan mulut untuk dilakukan pemeriksaan gigi dan beroleh pelayanan konseling.

\section{DAFTAR PUSTAKA}

1. Kemenkes RI. 2012. Buku Panduan Pelatihan Kader Kesehatan Gigi dan Mulut di Masyarakat, Direktorat Jenderal Bina Upaya Kesehatan, Jakata

2. Bahar, A. (2011). Paradigma Baru Pencegahan Karies Gigi. Fakultas Ekonomi Universitas Indonesia. Jakarta.

3. Kementerian Kesehatan RI., 2018. Riset Kesehatan Dasar, Badan Penelitian \& Pengembangan Tenaga Kesehatan Kemenkes. Laksana, Jakarta

4. Ngangi Rilly Sylvester, (2013) Gambaran Pencabutan Gigi Di Balai Pengobatan Rumah Sakit Gigi Dan Mulut Universitas Sam Ratulangi https://ejoumal.unsrat.ac.id/index.php/egigi/artic le/view/3211 diakses tanggal 14 Juni 2019

5. Volker \& Russel. (1993). Prevalensi Karies Gigi. EGC. Jakaìta

6. Tarigan, R. (2013). Kasehatan Gigi dan Mulut. EGC. Jakarta.

7. Harlindong (2014) Gambaran Tingkat Pengetahuan Siswa Tentang Pencabutan Gigi di $\begin{array}{llll}\text { SMP } & \text { Negeri } & 2 & \text { Lahendong }\end{array}$ https://eioumal.unsrat.ac.id/index.php/egigi/artic le/view/5779 diakses tanggai 5 April 2019 